\title{
Outcomes of Percutaneous Balloon Mitral Valvuloplasty in Significant Mitral Stenosis with Moderate Mitral Regurgitation - Single Center Study
}

\author{
Orta Derecede Mitral Yetersizliği Olan Anlamlı Mitral Darlığında \\ Perkütan Balon Mitral Valvüloplastinin Sonuçları - Tek Merkez Çalışması
}

\author{
(D) Ömer Çelik', (D) Ahmet Anıl Şahin², (D) Muammer Karakayalı¹
}

${ }^{1}$ Mehmet Akif Ersoy Thoracic and Cardivascular Surgery Training and Research Hospital, Clinic of Cardiology, İstanbul, Turkey
${ }^{2}$ Haliç University Faculty of Medicine, Department of Cardiology, İstanbul, Turkey

\section{Abstract}

Objective: Rheumatic heart disease is the deposition of immune complexes which cause malfunction of the heart valves. Percutaneous mitral balloon valvuloplasty (PMBV) is an established treatment option in patients with symptomatic moderate or severe rheumatic mitral valve disease, but PMBV is not a preferred option in mitral stenosis (MS) patients with moderate mitral regurgitation (MR) due to the risk of severe MR. The aim of this study was to evaluate the safety and feasibility of PMBV in symptomatic MS patients with moderate MR by comparing the post-procedural parameters with those of MS patients with mild or no MR.

Method: Among 104 patients with symptomatic MS, 10 patients with moderate MR were classified as group 2 while 94 patients who had mild or none MR were classified as group 1 in the present work. All patients underwent PMBV and pre- and post-procedural mitral valve area, MRs were recorded and cardiovascular events and complications were assessed in 30 days.

Results: The only difference in both groups before and after the procedure was the severity of the MR. Cardiovascular death was not observed for both groups in 30 days. In group 1, there were 3 patients and in group 2, there was 1 patient who developed severe MR after PMBV. All patients who had post-procedural severe MR required mitral valve replacement in 30 days due to severe MR in group 1. The composite complication rate was similar between the groups.

Conclusion: PMBV might be an alternative treatment option for selected patients having significant MS with moderate MR.

Keywords: Mitral valve regurgitation, mitral valve stenosis, mitral valve valvuloplasty

\section{Öz}

Amaç: Romatizmal kalp hastalığı, kalp kapakçıklarında fonksiyon bozukluğuna neden olan bağışıklık komplekslerinin birikmesidir. Perkütan mitral balon valvüloplasti (PMBV), semptomatik orta veya şiddetli romatizmal mitral kapak hastalığı olan hastalarda belirlenmiş tedavi seçeneğidir. Ancak şiddetli mitral yetersizliği (MY) oluşma riski nedeniyle orta derecede MY olan mitral darlığı hastalarında PMBV tercih edilmez. Bu çalışmanın amacı, orta derecede MY olan semptomatik MS hastalarında PMBV'nin güvenilirliğini ve uygulanabilirliğini, işlem sonrası parametrelerini hafif MY olan veya olmayan mitral darlık hastalarınınkilerle karşılaştırarak değerlendirmektir.

Yöntem: Semptomatik mitral darlığı olan 104 hastadan orta derecede MY olan 10 hasta grup 2, hafif MY olan veya hiç olmayan 94 hasta grup 1 olarak sınıflandırıldı. Tüm hastalara PMBV uygulandı ve işlem öncesi ve sonrası mitral kapak alanı, MY'leri kaydedildi ve 30 gün içinde kardiyovasküler olaylar ve komplikasyonlar değerlendirildi.

Bulgular: İşlem öncesi ve sonrası her iki gruptaki tek fark MY'nin ciddiyetiydi. Otuz gün içinde her iki grupta da kardiyovasküler ölüm görülmedi. PMBV sonrası şiddetli MY gelişen hasta sayısı birinci grupta 3 ve ikinci grupta 1 hasta idi. Grup 1'deki tüm ileri MY hastalarda şiddetli MY gelişmesi nedeniyle 30 günde mitral kapak replasmanı gerekti. Kompozit komplikasyon oranı gruplar arasında benzerdi.

Sonuç: PMBV, orta derecede MY ile belirgin mitral darlığı olan seçilmiş hastalar için alternatif bir tedavi seçeneği olabilir.

Anahtar kelimeler: Mitral kapak darlığı, mitral kapak yetersizliği, mitral kapak valvüloplasti 


\section{Introduction}

Rheumatic valvular disease (RVD) is the result of superficial deposition of immune complexes and complements on heart valves. The deposition occurs progressively after rheumatic fever and causes the malfunction and dysfunction of the heart valves (1). These depositions might result in fibrotic alterations in the valves, particularly in the mitral valve, which might result in stenosis of mitral valve. This stenosis might present as the impairment of diastolic filling, increase in systolic pulmonary artery pressure (SPAP), increase in pressure of left atrium, reduced preload with the symptoms of progressive dyspnea, and decreased functional capacity (2). PMBV is an established treatment option for patients who have RVD. PMBV might be used in patients with moderate to severe MS. To date, several studies have explored the potential benefit of PMBV in symptomatic significant MS and favorable valve morphology, which have yielded promising results (3-6). Despite the fact that it is a robust method, PMBV might not be a treatment option for some patients. PMBV is not the preferred option in patients who have MS with moderate mitral regurgitation (MR) due to the risk of the exacerbation of MR after PMBV (7). Surgical mitral valve replacement (MVR) is the established treatment choice for patients who have MS with moderate MR, as an alternative to PMBV. Nevertheless, MVR has several disadvantages compared to PMBV, including higher risk of infective endocarditis, life-long anticoagulation, and the negation of the metallic valve.

The evidence concerning the efficacy and feasibility of PMBV in patients with MS accompanying moderate MR is scarce since most of MS patients with moderate MR are referred to MVR in daily practice. On the other hand, some patients with MS who have moderate MR might be a candidate for $\mathrm{PMBV}$ as a bridging procedure, which will postpone the surgical intervention, improve acute cardiac functions, and relieve the heart failure symptoms in selected patients.

In this study, we aimed to investigate safety and feasibility of PMBV in symptomatic MS patients with moderate MR by comparing the post-procedural parameters with those of MS patients with mild or no MR.

\section{Materials and Methods}

This study was a retrospective cohort study evaluating the safety and outcome of PMBV in patients who had significant MS with moderate MR. The investigation conforms to the principles outlined in the Declaration of Helsinki. The study was approved by the local ethics committee. All participants gave a written informed consent before being included in the study. Patients were selected among cases admitted to the cardiology clinic of a community tertiary hospital between January 2016 and February 2019. First, we investigated 158 consecutive patients who had symptomatic and significant rheumatic MS (MVA $\left.<1.5 \mathrm{~cm}^{2}\right)$. A total of 46 patients who had unfavorable morphology of mitral valve such as left atrial thrombus, required cardiac surgery for any other indication, severe MR, moderate or severe valve dysfunction in other valves were excluded from the study.

All patients underwent a baseline physical examination. The presence of atrial fibrillation was evaluated and recorded with electrocardiography. Transthoracic and transesophageal echocardiography (TEE) were performed to all patients, and two-dimensional MVA, mitral valve gradients, SPAP and severity of MR were evaluated. MR severity was calculated and evaluated with effective regurgitant orifice area (EROA) and regurgitant volume (RV) (8). The favorable characteristic of the mitral disease for PMBV was assessed with the score of Wilkins and was calculated for every patient before the procedure (9). After echocardiographic evaluations, the patients with moderate MR ( $\mathrm{n}=18)$, who did not have any other contraindication for PMBV, were informed about the MVR and possible outcomes and complications of prosthetic valves. Among these patients, eight of them accepted surgical intervention for MVR, two of them rejected to have metallic prosthesis due to future possible pregnancies, five of them refused to be operated because of the risk of future metallic prosthesis complications and three patients had urgent PMBV due to acute pulmonary edema condition during their admission in the intensive coronary unit. Ten patients who refused to be operated or were unsuitable for the surgical intervention were informed about the risk of possible post-procedural MR after PMBV, which might be needed to treat with urgent surgery and informed consents were collected before the procedure. These 10 patients constituted group 2 while 94 patients who had mild or no MR were classified as group 1 in the present work.

All patients underwent PMBV in the catheter laboratory with the guidance of TEE during the procedure. PBMV was performed with a single balloon technique using Inoue Balloon. Initial balloon size was selected according to body surface area. Maximum balloon size was determined by the following formula: patient height $(\mathrm{cm}) / 10+10$ (10). The proper placement and dilation of Inoue Balloon were evaluated with TEE guidance and assessed by the operator 
with the synchronized views of both TEE and scopic view. After the dilation of the balloon, immediate calculations for mitral gradient and pulmonary artery systolic pressures were recorded.

After the procedure, all patients underwent post-procedural echocardiographic evaluation and two-dimensional (2D) MVA, mitral diastolic gradients, EROA, RV, SPAP were reevaluated for the patients. The changes in EROA, 2D-MVA, SPAP and mitral diastolic gradients before and after the procedures were calculated.

\section{Statistical Analysis}

All statistical tests were performed with a commercially available software program (Statistical Package for the Social Science (SPSS) 20.0 for Windows, Chicago, IL, USA). All continuous variables were checked for normal distribution by the Kolmogorov-Smirnov test and presented as mean \pm standard deviation while categorical variables were expressed as numbers or percentages. Chi-square test or McNemar test was used to compare categorical variables. Student t-test or paired sample test were used to compare continuous variables with normal distribution while MannWhitney U test or Wilcoxon test was used to compare the continuous parameters without normal distribution. $\mathrm{P}<0.05$ was considered statistically significant.

\section{Results}

A total of 104 consecutive patients, including 18 male $(17.3 \%)$ and 86 female $(82.7 \%$ ), with the mean age of $41.91 \pm 10.49$ years were included in the final study cohort. A total of 94 patients with MR EROA value $<0.20 \mathrm{~cm}^{2}$ were categorized in group 1 (none/mild MR) while 10 patients with MR EROA $\geq 0.20$ $\mathrm{cm}^{2}$ were classified under group 2 (moderate MR). Detailed demographics and echocardiographic parameters of each group and univariate comparison of these parameters are listed in Table 1. There was no statistical significance between the groups in terms of gender, age, pre-procedural and post-procedural SPAP, mean mitral gradients, 2D MVA, Wilkins score and presence of atrial fibrillation. Only difference for both groups before and after the procedure was the severity of the MR. The severity of MR, which was calculated by EROA, was found to be higher in group 2 before and after the procedure. When we compared the pre- and post-procedural echocardiographic findings, the mean 2-D MVA change in group 2 was $0.71 \pm 0.21$ while it was $0.78 \pm 0.29$ in group $1(\mathrm{p}=0.38)$. In the study, successful valvulotomy, which was defined as the increase of 2-D MVA $>50 \%$, was seen in 73 patients $(77.7 \%)$ after the procedure in group 1, while it was in 6 patients (60\%) in group 2 after the procedure $(\mathrm{p}=0.21)$.

Primary outcomes for both groups after the procedure are listed in Table 2. Cardiovascular death was not observed for both groups in 30 days. In group 1, there were 3 patients who required MVR in 30 days due to severe MR after the procedure. On the contrary, in group 2, there was one patient who had severe MR following the procedure; however, there was no requirement of MVR for this patient in 30 days. We

\begin{tabular}{|c|c|c|c|}
\hline Variables & $\begin{array}{l}\text { Group } 1 \\
(n=94)\end{array}$ & $\begin{array}{l}\text { Group } 2 \\
(n=10)\end{array}$ & $\mathbf{p}$ \\
\hline Gender M/F & $\begin{array}{l}16(17.1 \%) / 78 \\
(83 \%)\end{array}$ & $\begin{array}{l}2(20 \%) / 8 \\
(80 \%)\end{array}$ & 0.75 \\
\hline Age (years) & $41.41 \pm 10.62$ & $46.60 \pm 8.12$ & 0.087 \\
\hline $\begin{array}{l}\text { Pre-procedural PASP } \\
(\mathrm{mmHg})\end{array}$ & $51.39 \pm 16.80$ & $60.07 \pm 19.98$ & 0.10 \\
\hline $\begin{array}{l}\text { Post-procedural PASP } \\
(\mathrm{mmHg})\end{array}$ & $34.21 \pm 6.02$ & $37 \pm 4.80$ & 0.16 \\
\hline $\begin{array}{l}\text { Mean mitral gradients } \\
\text { (pre-procedural) }\end{array}$ & $16.44 \pm 5.51$ & $16.2 \pm 5.55$ & 0.89 \\
\hline $\begin{array}{l}\text { Mean mitral gradients (post- } \\
\text { procedural) }\end{array}$ & $5.11 \pm 1.33$ & $5.6 \pm 1.57$ & 0.28 \\
\hline $\begin{array}{l}\text { Pre-procedural 2-D MVA } \\
\left(\mathrm{cm}^{2}\right)\end{array}$ & $0.98 \pm 0.23$ & $1.09 \pm 0.23$ & 0.15 \\
\hline $\begin{array}{l}\text { Post-procedural 2-D MVA } \\
\left(\mathrm{cm}^{2}\right)\end{array}$ & $1.76 \pm 0.19$ & $1.79 \pm 0.73$ & 0.46 \\
\hline $\begin{array}{l}\text { Pre-procedural MR EROA } \\
\left(\mathrm{cm}^{2}\right)\end{array}$ & $0.08 \pm 0.05$ & $0.24 \pm 0.02$ & $<0.0001$ \\
\hline $\begin{array}{l}\text { Post-procedural MR EROA } \\
\left(\mathrm{cm}^{2}\right)\end{array}$ & $0.15 \pm 0.13$ & $0.27 \pm 0.038$ & 0.005 \\
\hline Wilkins score & $7.23 \pm 1.12$ & $7.10 \pm 1.128$ & 0.34 \\
\hline $\begin{array}{l}\triangle 2-\mathrm{D} M V A\left(\mathrm{~cm}^{2}\right) \\
(\text { mean } \pm \mathrm{SD})\end{array}$ & $0.78 \pm 0.29$ & $0.71 \pm 0.21$ & 0.38 \\
\hline $\begin{array}{l}\text { Presence of pre-procedural } \\
\mathrm{AF}(\mathrm{y} / \mathrm{n})\end{array}$ & $10(10.6 \%)$ & $1(10 \%)$ & 0.52 \\
\hline $\begin{array}{l}\text { Presence of post-procedural } \\
A F(y / n)\end{array}$ & 17 (18.1\%) & $3(30 \%)$ & 0.80 \\
\hline
\end{tabular}

PASP: Pulmonary artery systolic pressure $(\mathrm{mmHg})$, All variables are expressed as mean \pm standard deviations unless otherwise specified. SD: Standard deviation, EROA: Effective regurgitant orifice area, MR: Mitral regurgitation, MVA: Mitral valve area

Table 2. Primary outcomes of both groups after the procedure

\begin{tabular}{lll} 
& Group 1 & Group 2 \\
\hline Cardiovascular death within 30 days & $0(0 \%)$ & $0(0 \%)$ \\
MVR for severe MR within 30 days (n-\%) & $3(3.2 \%)$ & $0(\%)$ \\
Peri-procedural Complications (n-\%) & $1(1.8 \%)$ & $1(10 \%)$ \\
Composite (n-\%) & $4(4.3 \%)$ & $1(10 \%)$ \\
\hline
\end{tabular}

MVR: Mitral valve replacement, MR: Mitral regurgitation 
encountered only two major peri-procedural complications $(1.92 \%)$ in the present work. There was one patient each in both groups, who had peri-procedural complications. One of these patients had pericardial effusion, and the other patient had a pericardial hematoma following PMBV. Both of these patients needed to undergo surgical intervention given to pericardial effusion and hematoma.

Pre-procedural and post-procedural comparisons of echocardiographic parameters for each group are shown in Table 3 and Table 4. For the groups, SPAP and the mean mitral gradients significantly decreased, and 2-D MVA and MR EROA significantly increased. The rate for the presence of atrial fibrillation was found to be higher for both groups after the procedure; however, only in group 1, this increase was found as statistically significant.

\section{Discussion}

In this present study, we evaluated the outcome of PMBV as an alternative procedure to MVR in delicately selected MS patients accompanied by moderate MR. Our study demonstrated that cardiovascular death and post-procedural complication rates were similar when compared to patients who had MS with moderate and none or mild MR. Only one of ten MS patients accompanied by moderate MR manifested with severe MR after PMBV, and only 3 of 96 patients (3.1\%) with no or mild MR presented with severe MR after PMBV. As it is expected, the mean 2D-MVA of both groups was significantly increased after PMBV when compared to 2D-MVA before the procedure. Together with that, there was no significant difference between the groups in terms of mean increase in valve area after the procedure. Our study demonstrated that after PMBV, patients who had moderate MR with significant MS might had similar complication rates together with similar success rates when compared to the patients who had no or mild MR with significant MS.

Several studies have showed that the occurrence rate of severe MR in MS patients with mild or no MR after the procedure ranges between $1.4 \%$ and $9.4 \%$. And in these cases, $1.3 \%-3.2 \%$ required MVR urgently due to the occurrence of severe MR (11-13). However, there are inadequate data on the occurrence of severe regurgitation after PMBV in patients with MS having moderate regurgitation for mitral valve. In a study, they performed PMBV to 21 patients who had moderate MR and they compared the procedural outcomes with 83 patients who had no or mild MR (13). Even though the regurgitation progressed in both groups, no patient presented with severe MR after the procedure and together with the improvement in symptoms due to mitral valve disease. Similarly, both groups in the present work had an increase in the rate of MR. While no MS patient with moderate MR showed severe MR in the study conducted by Lau et al. (14), one patient with moderate MR (10\%) presented with severe MR after PMBV in our work. These results in previous studies are consistent with our findings for the occurrence of severe MR after the procedure.

On the other hand, we should discuss about the success rate of the procedure for patients who have moderate MR together with significant MS. In a study, Zhang et al. (15) performed PMBV in 25 patients who had MS with moderate

Table 3. Univariate comparison of pre- and post-procedural echocardiographic findings of group 1

\begin{tabular}{llll} 
Variables & Pre-procedural & Post-procedural & p \\
\hline Pulmonary artery systolic pressure $(\mathrm{mmHg})$ & $51.39 \pm 16.80$ & $34.21 \pm 6.02$ & $<0.0001$ \\
Mean mitral gradients $(\mathrm{mmHg})$ & $16.44 \pm 5.51$ & $5.11 \pm 1.33$ & $<0.0001$ \\
2-D MVA $\left(\mathrm{cm}^{2}\right)$ & $0.98 \pm 0.23$ & $1.76 \pm 0.19$ & $<0.0001$ \\
MR EROA $\left(\mathrm{cm}^{2}\right)$ & $0.08 \pm 0.05$ & $0.15 \pm 0.13$ & $\mathbf{0 . 0 0 0 1}$ \\
Presence of atrial fibrillation $(\mathrm{y} / \mathrm{n})$ & $10 / 84(10.6 \%)$ & $17 / 77(18.1 \%)$ & $\mathbf{0 . 0 1 9}$ \\
\hline
\end{tabular}

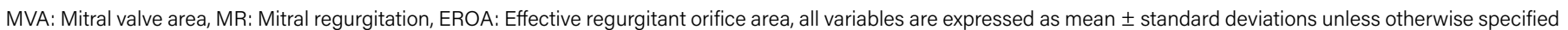

Table 4. Univariate comparison of pre- and post-procedural echocardiographic findings of group 2

\begin{tabular}{llll} 
Variables & Pre-procedural & Post-procedural & p \\
\hline Pulmonary artery systolic pressure $(\mathrm{mmHg})$ & $60.07 \pm 19.98$ & $37 \pm 4.80$ & $<0.0001$ \\
Mean mitral gradients $(\mathrm{mmHg})$ & $16.2 \pm 5.55$ & $5.6 \pm 1.57$ & $<0.0001$ \\
2-D MVA $\left(\mathrm{cm}^{2}\right)$ & $1.09 \pm 0.23$ & $1.79 \pm 0.73$ & $<0.0001$ \\
MR EROA $\left(\mathrm{cm}^{2}\right)$ & $0.24 \pm 0.02$ & $0.27 \pm 0.038$ & $\mathbf{0 . 0 2}$ \\
Presence of atrial fibrillation $(\mathrm{y} / \mathrm{n})$ & $1 / 9(10 \%)$ & $3 / 7(30 \%)$ & 0.15 \\
\hline
\end{tabular}

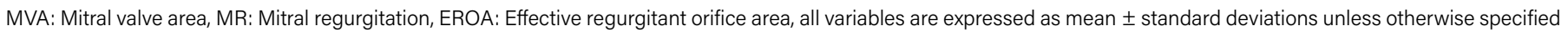


MR and compared their post-procedural findings with 25 patients who had MS with no or mild MR. Procedural successful rate for both groups was $92 \%$ in their study. Their findings showed that improvement in hemodynamics and MVA could be achieved with PMBV in patients who had MS either with moderate or no or mild MR. In our study, the success rate for procedures was $77.7 \%$ in group 1 and $60 \%$ in group 2; however, there was no significant difference between the groups. And improvement in MVA was accomplished in both groups.

One of the high volume studies is the study of Desabandhu et al. (16). They compared patients undergoing PMBV either with no or mild MR and moderate MR. In their study, 17 patients had moderate MR with significant MS and 208 patients had no or mild MR with significant MS. They found that there was no statistically significant difference in the primary outcome of the procedure in both groups. In their study, 2 patients (11.76\%) had post-procedural severe MR in patients with moderate MR and 4 patients (1.92\%) had post-procedural severe MR in patients with no or mild MR. Even though severe MR was higher in moderate MR group, the requirement for MVR was higher (1.44\%) in the group with no or mild MR. Their comment for their study was that PMBV might be a safe option for selected patients who had significant MS with moderate MR and provide symptomatic benefits in these patients. In our study, our findings were similar to their findings. Cardiovascular death was not seen for both groups in 30 days and 3 patients required MVR after the procedure due to severe MR in group 1 and one patient had severe MR which did not require MVR in group 2 in 30 days. The patient in group 2, who did not require MVR, was followed up with medical therapy. The possible explanation for the requirement of MVR might be that the patients with moderate MR have higher volume load than the patients with no or mild MR. Because of higher volume load in these patients, patients with moderate MR might better tolerate severe MR after PMBV when compared to the patients with no or mild MR. Together with that, there was no significant difference in peri-procedural complication in both groups. Composite complication of cardiovascular death and severe MR at 30 days was not different between the groups.

\section{Study Limitations}

Several limitations for the present study should be acknowledged. First, and foremost, we had a small number of MS patients with moderate MR, who underwent PMBV as similar to the previous works. Nevertheless, the indications for PMBV in MS patients with moderate MR are rather limited and strict; hence, it was not possible to form a balanced study group. Second, this was a retrospective study with single-center data, which might limit the generalizability and reliability of our results. Another limitation was the limited follow-up period for the patients and we did not have the results of longer period for both groups.

\section{Conclusion}

Outcomes for PMBV in patients who had MS with moderate MR are similar to those in the patients who had MS with no/mild MR. PMBV might be an alternative treatment option for selected patients who had significant MS with moderate MR. However, prospective further studies with larger patient cohort are needed to validate our results.

\section{Ethics}

Ethics Committee Approval: All procedures performed in the study involving human participants were in accordance with the ethical standards of the institutional and/or national research committee and with the 1964 Helsinki declaration and its later amendments or comparable ethical standards.

Informed Consent: Written informed consent was obtained from all participants.

Peer-review: Externally peer-reviewed.

\section{Authorship Contributions}

Concept: Ö.Ç., A.A.Ş., M.K., Design: Ö.Ç., A.A.Ş., M.K., Data Collection or Processing: Ö.Ç., A.A.Ş., M.K., Analysis or Interpretation: Ö.Ç., A.A.Ş., M.K., Writing: Ö.Ç., A.A.Ş., M.K.

Conflict of Interest: No conflict of interest was declared by the authors.

Financial Disclosure: The authors declared that this study has received no financial support.

\section{References}

1. Kaplan MH, Bolande R, Rakita L, Blair J. Presence of bound immunoglobulins and complement in the myocardium in acute rheumatic fever. Association with cardiac failure. N Engl J Med 1964;271:637-645.

2. Gorlin R. The mechanism of the signs and symptoms of mitral valve disease. Br Heart J 1954;16(4):375-380.

3. Inoue K, Owaki T, Nakamura T, Kitamura F, Miyamoto N. Clinical application of transvenous mitral commissurotomy by a new balloon catheter. J Thorac Cardiovasc Surg 1984;87(3):394-402.

4. Vahanian A, Michel PL, Cormier B, Vitoux B, Michel X, Slama M, et al. Results of percutaneous mitral commissurotomy in 200 patients. Am J Cardiol 1989;63(12):847-852.

5. Fawzy ME, Mimish L, Sivanandam V, Lingamanaicker J, al-Amri M, Khan B, et al. Advantage of inoue balloon catheter in mitral 
balloon valvotomy: experience with 220 consecutive patients. Cathet Cardiovasc Diagn 1996;38(1):9-14.

6. Iung B, Garbarz E, Michaud P, Helou S, Farah B, Berdah P, et al. Late results of percutaneous mitral commissurotomy in a series of 1024 patients. Analysis of late clinical deterioration: frequency, anatomic findings, and predictive factors. Circulation 1999;99(25):32723278.

7. Nishimura RA, Otto CM, Bonow RO, Carabello BA, Erwin 3rd JP, Guyton RA, et al. 2014 AHA/ACC guideline for the management of patients with valvular heart disease: executive summary: a report of the American College of Cardiology/American Heart Association Task Force on Practice Guidelines [Erratum in J Am Coll Cardiol 2014;63(22):2489]. J Am Coll Cardiol 2014;63(22):2438-2488.

8. Zoghbi WA, Adams D, Bonow RO, Enriquez-Sarano M, Foster E, Grayburn PA, et al. Recommendations for noninvasive evaluation of native valvular regurgitation: a report from the American Society of Echocardiography developed in collaboration with the Society for Cardiovascular Magnetic Resonance. J Am Soc Echocardiogr 2017;30(4):303-371.

9. Wilkins GT, Weyman AE, Abascal VM, Block PC, Palacios IF. Percutaneous balloon dilatation of the mitral valve: an analysis of echocardiographic variables related to outcome and the mechanism of dilatation. Br Heart J 1988;60(4):299-308.

10. Palacios IF. Percutaneous mitral balloon valvuloplasty. In: Percutaneous Interventions for Congenital Heart Disease, Sievert H, Qureshi SA, Wilson N, Hijazi ZM (editors). London: Informa Healthcare, 2007:177e184.
11. Nobuyoshi M, Arita T, Shirai S, Hamasaki N, Yokoi H, Iwabuchi $\mathrm{M}$, et al. Percutaneous balloon mitral valvuloplasty: a review. Circulation 2009;119(8):e211-e219.

12. Kaul UA, Singh S, Kalra GS, Nair M, Mohan JC, Nigam M, et al. Mitral regurgitation following percutaneous transvenous mitral commissurotomy: a single-center experience. J Heart Valve Dis 2000;9(2):262-266; discussion 266-268.

13. Nanjappa MC, Ananthakrishna R, Hemanna Setty SK, Bhat P, Shankarappa RK, Panneerselvam A, et al. Acute severe mitral regurgitation following balloon mitral valvotomy: echocardiographic features, operative findings, and outcome in 50 surgical cases. Catheter Cardiovasc Interv 2013;81(4):603-608.

14. Lau KW, Ding ZP, Koh TH, Johan A. Percutaneous inoue-balloon mitral commissurotomy in patients with coexisting moderate mitral regurgitation, and severe subvalvular disease and/or mitral calcification. J Invasive Cardiol 1996;8(2):99-106.

15. Zhang HP, Gamra H, Allen JW, et al. Balloon valvotomy for mitral stenosis associated with moderate mitral regurgitation. Am J Cardiol 1995;75(14):960-963.

16. Desabandhu V, Peringadan NG, Krishnan MN. Safety and efficacy of percutaneous balloon mitral valvotomy in severe mitral stenosis with moderate mitral regurgitation - A prospective study. Indian Heart J 2016;68(6):783-787. 